\title{
The Legal Responsibility of the Guarantor of Those Who Are Bound by the Commercial Paper in The Jordanian Law"
}

\author{
Dr. Mohammed Ali Mohamed Bani Migdad \\ the Hashemite Kingdom of Jordan, Ajloun National University, College of Law
}

\begin{abstract}
The importance of the collateral for the commercial paper is one of the most important guarantees granted by the law to the holder of this commercial paper, which is reflected in the legal relationship between the parties committed to fulfilling them, especially the obligation of the guarantor in his original and subordination capacity , and the consequent effects of this legal relationship between the guarantor and the holder and the consequences of this obligation.

The legal relationship between the reserve guarantor and the secured person and the rest of the obligators in the commercial paper may raise legal problems among them. This is evidenced by legal texts related to the effect of collateral and the presentation of jurisprudential opinions on this subject and the available judicial rulings.

In this paper, an attempt is made to work out a methodology for comparative legal research which goes beyond the functional method . the researcher aims at using the comparative method as an instrument of learning and knowledge . In addition, the researcher is contributing to his own legal system : understanding it better , improving it, and using it as a means for interpreting the legal laws and legislations .

The researcher explained the legislative shortcomings that have characterized the provisions of this relationship. He recommends that there is a need to review the drafting of some legal texts in a manner consistent with the legal problems that may arise from the relationship between the parties of the collateral .
\end{abstract}

Key words: collateral , commercial paper, Jordanian legislator, guarantor, obligator, holder , drawer.

DOI: $10.7176 / J L P G / 83-14$

Publication date: March $31^{\text {st }} 2019$

\section{Introduction}

The collateral was regulated by the Jordanian legislator in articles 161-163 of the Jordanian Trade Law No. 12 of 1966, but this law, like other legislations ${ }^{(1)}$, did not include an explicit definition of the collateral. The jurisprudence differed in its definition. However, the unanimous view was that the collateral is the guarantee of the fixed debt in the whole or part of the commercial paper, provided that the guarantor commits to pay the bond on the due date in case of non-fulfillment by the secured obligator ${ }^{(2)}$.

The importance of collateral is to increase the guarantees granted by the law to the holder of the commercial paper. The business activity is based on credit, supported by a set of legal guarantees for the holder, which is reflected in the offer of the paper to the drawee for acceptance, and the solidarity of all signatories in fulfilling its value on time or determinable. However, these legal guarantees may not be sufficient, which makes the beneficiary of the commercial paper looking for other guarantees to ensure his right to fulfill the value, especially in cases where the holder is not sure of the debtor's ability to fulfill the value of the commercial paper on the maturity date. A collateral is a personal guarantee that may be made by any person, whether from a third party or from one of the signatories of the commercial paper. Article 161 of the Jordanian Trade Law authorizes the provision of the collateral to fulfill the value of the bond in whole or in part. Article 162, paragraph 3, requires that the name of the secured person be mentioned in the security form, otherwise the collateral shall be considered for the drawer, and thus a collateral may be incurred by any party committed to pay the value of the commercial paper.

The guarantee may occur on the same bond or on a separate bond to relieve the embarrassment of the bondholders, especially the secured person, because of the doubts about their financial position when the guarantee occurs on the bond itself. If the collateral is signed on a separate sheet of paper, the guarantor shall be bound only by the person who signed the guarantee without the other, article 162/6. Therefore, The reserve 
guarantor intervenes to ensure that the drawer complies with the first beneficiary of the bond. The guarantor shall not be liable to the beneficiary other than the other bondholders. If the guarantor's signature is on the same sheet or the paper attached thereto, the guarantor is obliged to pay the value of the commercial paper to all subsequent signatories ${ }^{(3)}$.

There is a difference between the guarantee in the check and the collateral in the withdrawal bond. The bank that withdraws the check may not provide the guarantee because its role is limited to the credit of the check. Therefore, the collateral is rare in the check in terms of the practical life of the check, and the fact that the holder guarantees an obligation to pay, except for the certified or approved check created by the banking custom, and the drawee in the withdrawal bond can be a reserve guarantor because he can refuse to sign the acceptance of the bond. The relationship with the withdrawal bond may be limited to the drawer, the drawee and the beneficiary. This relationship may extend to other persons as a result of the endorsement or acceptance of the bond or the guarantee of a party to a collateral so that everyone who signed the paper is bound by morphological obligation to fulfill its value. The researcher will focus on the legal relationship resulting from the collateral in the commercial paper that links the collateral with the holder, the guaranteed and with other obligators by explaining the legal effects of the collateral in the commercial paper with emphasis on the withdrawal bond as the basis for the rest of the commercial papers.

\section{Methodology}

The aim of the research is making some part of the domestic law more coherent, one may do without external comparison. It also aims to harmonize the law as the focus will be on the commonalities, on the common core of the compared legal systems and on the possible ways of erasing differences. When one tries to improve his own legal system, as a legislator or as a scholar, it has become clear to at the other side of the borders. Nevertheless, importing rules or solutions from other countries may not work because of the differences in contexts. As a result, a more thorough contextual approach is needed. The collateral was regulated by the Jordanian legislator in articles 161-163 of the Jordanian Trade Law No. 12 of 1966, but this law, like other legislations, did not include an explicit definition of the collateral. The researcher explained the legislative shortcomings that have characterized the provisions of these articles .

\section{DISCUSSION}

\section{THE RELATIONSHIP OF THE GUARANTOR WITH THE HOLDER.}

The collateral is a morphological commitment whereby the reserve guarantor intervenes by ensuring that the secured debtor complies with all the obligations stipulated in the commercial paper and is responsible for fulfilling it in solidarity towards the holder, whether the latter is the first beneficiary or the holder of the bond with a series of endorsements, in accordance with Article $163 / 1^{(4)}$, which is understood to mean that the reserve guarantor is bound by the holder of the bond, as is the case with the secured debtor, which acts as a joint surety in solidarity with the secured debtor against the holder. In order for the holder to return to the reserve guarantor, it is necessary to state the nature of the legal rules that govern the obligation of the guarantor towards the holder whether related to the rules of the exchange law and the rules of joint liability. The commitment of the reserve guarantor is both an accessory and original obligation at the same time. The researcher divides this study into two sections: studying the implications of the subordination of the commitment of the reserve guarantor in relation to the holder and studying the implications of the original commitment of the reserve guarantor in relation to the holder.

\section{SECTION ONE}

\section{The Effect Of The Subordination Of The Guarantor's Obligation In Relation To The Holder.}

The reserve guarantor considers his commitment as a subordinated liability within the limits to which the secured debtor is committed. The reserve guarantor is a joint shareholder with the secured debtor and with the rest of the signatories on the commercial paper as a subsequent business of the commercial paper. This leads to several fundamental results regulating the relationship between the guarantor and the holder : 


\section{First: Returning the holder to the reserve guarantor}

The guarantor shall be bound by the obligation of the secured person, and the holder shall have absolute freedom to return to the secured obligor first or to the guarantor or both and here we must distinguish between the presence of a single joint surety or more than one. In the first case, when the holder makes his claim to the guarantor, the guarantor can not first demand that the secured person be stripped of his funds before returning to him. Second, in the case of multiple reserve guarantors, the reserve guarantor can not hold on to the advantage of defense by dividing. In other words, the reserve guarantor can not force the holder to divide the debt between him and the secured obligor and divide the debt with multiple reserve guarantors ${ }^{(5)}$. It is possible that the reserve guarantors are more than one and become by their signatures joint in the fulfillment of the paper value even if not agreed with them explicitly because joint liability is assumed by law. In this case, the holder of the commercial paper is entitled to return to them all or one of them. In order for the holder to return to the reserve guarantor, the guarantor must be aware of this guarantee and this is only if the guarantor signed the commercial paper ${ }^{(6)}$. If this holder endorses the bond and transfer his right of the guarantee to the endorsee , it is considered as a transference. Thus, the guarantor has the right to insist on the defense against the holder ,whom the guarantee was issued in his favor, since the relationship between the guarantor and the holder is based on the principle of the independence of signatures and pursuant to the provisions of articles 162/4 and 181, which specified cases in which the holder may return to the obligors in the commercial paper and therefore the guarantor can not exempt himself from recourse .

\section{Second: The guarantor is not entitled to deprivation defense.}

The guaranteed, whether a drawer or drawee or transferor, has a commercial and joint obligation regardless of the guarantor and the reason for his guarantee ${ }^{(7)}$. Once the guarantor signs the commercial paper, his commitment is considered a disbursement obligation in his relationship with the lenders, as the legitimacy of the holder's right gives him the power to demand those who are committed to it, especially the reserve guarantor who can not evade his obligation. If the guarantee is on the front of the paper, the reserve guarantor may not be against the secured holder that is to say, returning to him first before the claim of the reserve guarantor or ask the holder to first pursue the debtor or the original debtors, such as the drawee, the drawer or any guaranteed person, as the holder has absolute freedom to return first to the secured obligor or to the reserve guarantor or both. The reserve guarantor may not pay on terms when there are other reserve shareholders ${ }^{(8)}$ so that he will only be obligated to the extent of his share in the debt. If the debtor has determined its obligation less than the amount of the bond as it is for the drawee who is partially acceptor, the reserve guarantor also commits only to pay the acceptable part ${ }^{(9)}$. Also, The reserve guarantor is entitled, on the basis of the subordination of his obligation, to defense against the good-faith holder with the set-off that may occur between the holder and the guaranteed committed person or for other reasons that are in his favor ${ }^{(10)}$. The reserve guarantor is not entitled to defense the holder to ask the guaranteed first unless it is stipulated in the guarantee clause because this is not in the public order ${ }^{(11)}$.

\section{THIRD: The Loss Of The Right Of The Negligent Holder To Return To The Reserve Guarantor.}

The negligent holder's right to return to the guarantor shall be dropped within the limits of the guaranteed. If the guarantor is a guarantor for the drawer who offer for the fulfillment, the guarantor shall hold defense against the negligent holder. However, if the collateral for the account of the acceptor drawee or the drawer who doesn't offer for the payment, the guarantor can not defense against the holder, even if the latter is negligent as the drawer ${ }^{(12)}$. If the collateral for the endorser account, the guarantor may insist on defense by the negligence of the endorser towards the holder.

The reserve guarantor shall have the right to defense by prescription within the limits of the guaranteed due to negligence if the holder does not carry out the procedures prescribed by the law on the prescribed dates. However, the limitation of actions shall vary according to the guaranteed person. If the guaranteed person is the acceptor drawee on whom the guarantor has the right to invoke prescription against the holder after five years from the date of maturity 214/1. If the guaranteed person is the drawer, or one of the endorsers, the reserve guarantor has to adhere to the prescriptions two years from the date of the protest filed on time or from the due date if the bond includes the provision of return without expenses. The loss due to negligence if the collateral for the account of the drawer, the guarantor guarantees all signatories of the commercial paper, including the drawer, and if the guarantee to the account of the drawee, the guarantor can not uphold the loss of the holder's right due to the legal procedures related to the right of recourse ${ }^{(13)}$. 
.

\section{SECTION TWO}

\section{THE EFFECT OF THE ORIGINAL OBLIGATION OF THE GUARANTOR IN RELATION TO THE HOLDER.}

The rules of exchange are the set of rules contained in articles 123-289 that regulate the regulation of commercial papers since its inception to its expiration, in particular with respect to the principle of independence of signatures and the rule of disqualification of defenses, that is, the non-invocation of personal defenses against a good-faith holder. We will explain the consequences of the reserve guarantor's commitment as a basic obligation to the exchange rules as follows:

First: the obligation of the reserve guarantor is considered a valid obligation even if the obligation of the guaranteed debtor is null and void

The principle of the independence of signatures means the independence of the obligation of each signatory on the commercial paper for the obligations of the other signatories and that each of these obligations is selfcontained. This principle is reflected in the case where one signatory's obligation is void because of a lack of eligibility or a false signature. Therefore, the obligation of the reserve guarantor is valid even if the obligation of the guaranteed is null and void for any reason other than in respect of the reasons related to the form ${ }^{(14)}$. However, the reserve guarantor may dispose of his banking obligation if the commercial paper is void of a defect in the form for not mentioning or missing one of the mandatory data such as the naming of the withdrawal document or the signing of the drawer ,etc....unless the guarantor was not a world in the matter. In this case, the obligation of the guarantor is void and the guarantor can hold the void because this defect is apparent and any signatory on the bond can stick to this invalidity ${ }^{(15)}$ because the defect is related to the bond itself and not to the firm commitment to it.

Second: The reserve guarantor may not hold against the good-faith holder in the personal defenses that he has on one of the signatories.

The rule of disqualification of defenses is to guarantee the right of a good-faith holder to obtain the value of the commercial paper against the debtor, including the guarantor, provided that the holder is not in a personal relationship with the debtor. The debtor shall not be liable in any way whatsoever as a drawer or a guarantor to hold on the defense against the good- faith holder, and this is what we shall indicate in the following points.

\section{1-Originally, The reserve guarantor shall not hold against the holder with personal defenses.}

In accordance with Article 147 of the Commercial Law and in accordance with the rule of disqualification of defenses, the fixed right in the bond shall be transferred from the endorser to the endorsee without any defenses based on the personal relations between the parties of the bond, giving these new rules a guarantee for the bond holder. This is what was taken by the Jordanian Court of Cassation, and this is an exception to the general rules in the Civil Code, because ,according to the general rules, the right moves from the assignor to the creditor with all the faults and the defenses that resulted from $i^{(16)}$. The assignee can uphold all the defenses related to debt, which he has the right to uphold in against the assignor or his defenses towards the assignee. We conclude from this rule that there are defenses that the guarantor may not hold against the good-faith holder. And there are defenses that he may hold against the holder even if he is of good faith. And good faith is presumed in the holder, and if the debtor claims the bad faith of this holder, he has the burden of denying this presumption by all means of proof ${ }^{(18)}$.

\section{2 - Permissibility to adhere to formal defenses against the holder}

The reserve guarantor may hold the formal defenses against the holder, even if he is of good faith, because the legislator provided the necessary data for the validity of the commercial paper ${ }^{(19)}$. When these data are not fulfilled, it is considered null and void, so there is no cleansing of the defenses because the whole matter is about the invalidity of the paper itself. Accordingly, the debtor has the right to raise defense in the absence of one of these statements especially the essence of the claim, in the face of all claims of entitlement to the fixed right. This applies to the guarantor being committed to the obligation of the guaranteed. 
3- defense of counterfeiting signature of the guarantor and the guaranteed.

A signature is a mandatory statement in all commercial papers that must be on the same bond and an indicator to the personality of its owner and expresses the consent of its owner to the obligation. If this signature is false, the satisfaction of its owner shall be null and void. Thus, the moral commitment is absent. The counterfeit may be the signature of the guarantor or the guaranteed person. Is it permissible for these people to stand in the face of the holder by the invalidity of their obligation, and is it permissible for any other member who has signed the commercial paper correctly to raise defense by falsifying another signature as a fixed right for each signatory on the commercial paper? We will show it as follows:

\section{A-Counterfeiting Signature Of The Reserve Guarantor.}

The collateral shall be subject to the application of the requirements of Article 130/1(20) upon falsification of the signature of the guarantor. The result shall be the granting of the right to the owner to raise defense of the counterfeit against each holder of the bond, even if he has good intention of his unwillingness to establish the claimed right. However, adherence to this defense is limited to those whose signature was forged in accordance with the principle of the independence of signatures ${ }^{(21)}$. Therefore, the rest of the signatories will not be disrespectful of their moral obligation, even if one of them was previously a fraudulent act, such as the obligation of the drawer or receiver or one of the former signatories as well as the subsequent signatories of the forgery. subsequent signatories of the forgery.

\section{B- Counterfeiting Signature Of The Guaranteed.}

We conclude from the text of article 163.2 that the guarantor can not protest against the invalidity of the obligation of the guaranteed in case of incapacity or satisfaction, or falsifying his signature against the holder, but the right to raise such defense is limited to the victim of the forgery. On the other hand, the formal defect here is not limited to the omission of one of the mandatory statements in the bond, but may even include the formal defect in the obligation of the guaranteed, such as the collateral provided for the endorser whose signature was placed on the front of the bond although the abstract signature is to be placed on the back of the bond in order to be considered endorsement. The collateral is provided in the interest of a person who is not considered to be liable as the drawee who did not sign the acceptance $^{(22)}$.

The French jurisprudence ${ }^{(23)}$ goes even further as it considers that the independence of the guarantor's obligation to the obligation of the original debtor is not full. The right of the guarantor to raise the defense of the nullity of the guaranteed obligation is not limited to the formal defect of the obligation of the guaranteed only but also the defense of the built-in defects on the basis of the expiration of the obligation. Some French jurisprudence concluded to say that the purpose of the collateral is to provide adequate protection to the good- faith holder to enable him to benefit from the collateral as additional one to him.

\section{4 - The defenses which the guaranteed adheres against the holder.}

Article 163/1 shows that it adapted the obligation of the guarantor in the same manner as the guaranteed, and we find that the second paragraph of the same article contradicts with the first paragraph by drafting it when the guarantor's obligation is considered to be true even if the obligation of the guaranteed is null and void for any reason unless the defect comes in the shape. And from our analysis of these paragraphs, we can not say in the original that the guarantor to stick to all defenses that the guaranteed is entitled to stick against the holder in contradiction with the content of Article 147 and the second paragraph of Article 163 this on the one hand, and on the other hand, it is not possible to say that the final guarantee of the guaranteed in relation to the holder is not in compliance with the provision of the second paragraph of article 163 , which ,in the first, made the obligation of the guarantor a subsequent obligation and the latter made a purely original obligation. If his obligation is subordinated, he has the right to hold all the defenses which the guaranteed is entitled to uphold, and the obligation of the guarantor shall be dependent on all the circumstances in which the guaranteed disposes of his obligation either for limitation or set-off or for any cause of the expiration of the obligation or defect in the form. If the holder returns to the guarantor and the latter is a creditor to the holder, the discharge of debt is due. Therefore, the holder is not entitled to claim the guarantor upon discharge of the original debtor ${ }^{(25)}$. In order to take these morphological rules, in particular the rule of disqualification of defenses, the holder must not be illintentioned because the element of good faith makes the holder worthy of protection. Otherwise, the debtor may be entitled to raise the defenses ${ }^{(26)}$. If the holder is ill- intentioned, the reserve guarantor will be able to hold all the defenses related to the secured obligation and the defenses of nullity of the guarantee but the guarantor is not entitled to uphold the personal defenses ${ }^{(27)}$. 


\section{SECTION TWO}

\section{THE RELATIONSHIP BETWEEN THE GUARANTOR AND THE GUARANTEED AND THE REST OF THE OBLIGORS}

The legal relationship between the guarantor and the rest of the other obligators is regulated by Article 163 of the Commercial Law : if the guarantor pays the value of the commercial paper to the holder, the guarantor shall have the right of return to all the obligors of the guaranteed obligor. However, the legal status of the reserve guarantor varies depending on whether the collateral is provided to one person who may be the drawer, the drawee or the endorser. In the case of the multiple reserve guarantors to meet the value of the commercial paper as if the guarantee is given to two different signatories : such as one may ensure the drawer, the second ensures the drawee and the third may ensure the endorser. In this case, the reserve guarantors are committed to the holder on the solidarity. The holder can follow them individually or in groups with the amount of bond and the subsequent benefits and expenses without any of them can adhere to the advantage of defense on terms. If the holder returns to one of the guarantors to fulfill, this guarantor is not entitled to claim the holder to return to the second guarantor and the holder has the right to bring the case against them without being obliged to follow the order in which their commitment was made ${ }^{(28)}$. What concerns us in this relationship is the collateral provided for one guaranteed. Thus, the secured obligor must be defined as an unambiguous reserve in order to determine the status of the guarantor, which makes the commercial law its rights and obligations derived from the rights and obligations of the obligor in accordance with article 163/1, we shall clarify these relations in the following two requirements:

\section{THE GUARANTOR'S RELATIONSHIP WITH THE GUARANTEED.}

the guarantor acts as a joint surety with his guaranteed, as regulated by article 163/1, since the guarantor guarantees the secured person, including the subsequent signatories, and at the same time is guaranteed by all the signatories of the person to whom it is guaranteed ${ }^{(29)}$. In the event that the guaranteed person determines his obligation, this limitation applies to the obligation of the guarantor because the latter does not commit to more than the guaranteed commits himself to ${ }^{(30)}$, i.e the guarantor shall be placed in the same legal position as the guaranteed in terms of his duties. The guarantor shall therefore designate the name of the secured obligor who enters into his guarante ${ }^{(31)}$ and the fact that the provisions of the collateral are not related to the public order or may be agreed upon in contravention of these provisions.

The guaranteed person is only bound by the guarantee of fulfillment or by the guarantee of acceptance . And the guarantor is bound by the guarantee of fulfillment and acceptance only. If the guaranteed is committed to ensuring fulfillment, acceptance or the value of the paper in whole or in part. Because the provisions of the collateral are not related to public order, it is permissible to agree on what is contrary to these provisions ${ }^{(32)}$. Therefore, the guarantor guarantees the two subsequent signatories and at the same time the two former signatories to sign the guaranteed. It is clear from this text that the effects of the collateral in the relationship between the guarantor and the guaranteed have the following results, which will be detailed as follows:

\section{First: The guarantor shall be considered a joint surety for the guaranteed and in solidarity with him.}

The commitment of the guarantor is a consequential obligation that is based on the obligation of the guaranteed. The obligation of the guarantor remains valid even if the obligation of the guaranteed is null and void, in accordance with the principle of the independence of signatures and the provisions of article 163/2. There is no exception except the invalidity based on a defect in the rules of form such as leaving some mandatory data because the nullity in such case has to do with the bond itself, not the fixed obligation of it . In such cases, the reserve guarantor may claim invalidity in the face of the holder ${ }^{(33)}$ and the holder has the right to require the guarantor to pay the full value of the commercial paper unless the collateral is conditional on partial fulfillment or when his obligation is limited by the debtor's inability or obligation .In other words, in the sense that the guarantor is not obligated to fulfill unless the secured person is unable to pay the value of the commercial paper on the basis of the lawsuit without returning to the secured obligor, although the obligation of the guarantor as a guarantor is in accordance with the obligation of the guaranteed in accordance with article $163 / 1$ because solidarity is assumed between them and a decision by virtue of law. So the reserve guarantor may not uphold the invalidity except in the face of those whom the guaranteed can adhere before them within the scope of the rule of clearance of defenses. The solidarity character of the guarantor's obligation with the guaranteed in the commercial paper is similar to that of the guarantor in accordance with the provisions of Article $967 / 1$ of the Jordanian Civil Code, and contrary to what some have said : the obligation of guarantor with the guaranteed is different from the obligation of the bailer in the civil debt, where the difference between 
them shows that in ordinary debts, the guarantor is obliged to pay only if the debtor is unable to pay. And in case of having several guarantors, in such a case, the guarantor is only committed to the amount of his share of the bail $^{(34)}$. The guarantor shall be responsible for the payment of the value of the paper for all the creditors who have come after signing the security document. The guarantor of the drawer is obliged to guarantee the acceptance of the commercial paper and the fulfillment of its value in case the drawee does not accept it ${ }^{(35)}$. He is also asked to fulfill before all creditors. If the guarantee is allocated to the drawee on it or to one of the two endorsers, the guarantor asks for the fulfillment of the signatories who signed the bond after the signing of the drawee or after endorser. If the collateral is allocated to the drawer, the guarantor does not comply only with what is committed by the drawer.

Second: The transfer of the rights arising from the commercial paper for the guarantor upon his fulfillment of its value.

The guaranteed is the original obligor of fulfilling the value of the commercial paper . If it is fulfilled by him, it is not for him to return to the guarantor. Article 163/1, however, states that if the full amount of the paper is paid by the guarantor, all the rights arising there from shall be transferred to him, whether the guaranteed or the other obligors towards him with the interest and expenses pursuant to Article 187 of the Commercial Code . The guarantor of the drawer has no right to return except to the drawer and the drawee ${ }^{(36)}$, who was paid for the fulfillment, while the reserve guarantor of one of the endorsers may be due to this endorser and the previous endorsers, as well as the drawer and drawee. It can be explained in the following example: the holder endorsed the commercial paper for the endorser (a) then to the endorser (b), and then to the endorser (c) then to the endorser (d). The person (f) is a guarantor of the endorser (c). The reserve guarantor(c) fulfills the value of the commercial paper for (d) as the last holder of the paper. The guarantor(f) may return to the guaranteed (c) and the other obligors (a) $+($ b) .Thus, if the guarantor fulfill the value of the commercial paper, the holder may ask him to hand over the bond to him to exercise his right before whom accepted to guarantee him and the previous obligors on the secured obligor ${ }^{(37)}$. The reserve guarantor shall return to the guaranteed for the purposes of the refund of the amount paid to the holder, either on the basis of the payment action resulting from becoming the holder of a bond after the fulfillment of its value or according to the personal suit prescribed for the bailer in accordance with the general rules. And the right of recourse to the guarantor on the remaining obligors who ensure the secured obligor is not as a holder because Substitution is not to the guarantor only to the secured person but as an alternative of the secured obligor and therefore the guarantor may not refer to the subsequent obligors because the guaranteed is the one who guarantees them. So, the reserve guarantor takes the position of the guaranteed in the series of signatures in the commercial paper, but it is not considered a special successor to the secured person and therefore does not invoke the defenses against which the guaranteed is invoked. Since the relationship between the collateral guarantor and the secured person is subject to the rules of commercial law, some said that ${ }^{(38)}$ this similar to the relationship between the endorser and the endorsee, which means that the defenses between the guarantor and the guaranteed may be raised, and therefore the secured person may not raise any defense resulting from previous relationship in the face of the reserve guarantor unless such defect is formal .

The guarantor's relationship with the persons committed to the secured person from the former signatories on the withdrawal bond. The reserve guarantor has acquired the right to fulfill the value to the legal holder by reference to those committed in accordance with the rules of recourse. Some have argued ${ }^{(39)}$ that it is not possible to say that the guarantor in his return to those committed to the fulfillment is in place of the endorsee in his relationship with the secured person since this matter does not endorse the paper to him, and therefore can not rely on the basis of endorsement and the clearance of the defenses in relation to those committed to the extent that the person can rely on them against the guaranteed person. He has to rely on him in the face of the guarantor on any committed person for any reason, he of course to ask the secured person what he fulfilled on his behalf.

\section{THE RELATIONSHIP OF THE GUARANTOR WITH THE OTHER COMMITTED OBLIGORS}

\section{SECTION 1: THE RELATIONSHIP OF THE RESERVE GUARANTOR WITH THE DRAWER:}

The reserve guarantor may only place his signature on the front of the paper. In this case, the legislator established in accordance with article 162/4 a presumption that does not accept the contrary evidence for the good- faith holder that this signature is a collateral if the signature of the drawer or drawee is not possible. Because the legislator wants to allocate the front of the bond to signature of the drawer, the drawee and the guarantors, and the back of it to the signature of the endorsers as it was the commercial custom. Therefore, if 
the name of guaranteed is not assigned, the legislator establishes this presumption that the guarantee was for the account of the drawer, because the drawer is responsible for the fulfillment before all previous signatories ${ }^{(40)}$

When the collateral has been signed on the behalf of the drawer, the position of the guarantor in the face of the holder is determined by the status of the guaranteed and has the defense against the holder's right of recourse in cases where the drawer may adhere to this right in the face of the holder. If the guarantor fulfills the value of the commercial paper of the holder, the reserve guarantor must return to the drawee who has received the payment. It is not permissible to return to the following endorsers. As a result, it is not permissible for the drawee, in case of recourse, to protest against the guarantor that he has not received payment for the fulfillment ${ }^{(41)}$. And we agree with some in this attitude ${ }^{(42)}$ : they believe that the reserve guarantor is committed to the manner in which the guaranteed is committed and does not commit to more than the commitment of the secured person, Therefore, the guarantor may not be invoked in defenses that the former signatories are committed to the secured person. Thus, the reserve guarantor of the bond's issuer takes the legal status of the entrepreneur.

The predominant view in jurisprudence is that claims are subject to the provisions of the statute of limitations because they are based on the substitution of the reserve guarantor in place of the guaranteed ${ }^{(43)}$ on the basis that the reserve guarantor shall be given a role in the payment process according to the exchange law.

\section{Section II: The relationship of the guarantor with the drawee and the endorser.}

If the reserve guarantor intervenes for one of these: the drawee or any of the endorsers, he will have the right of recourse against whoever intervenes in his favor, and this is what we will explain in the following two items.

\section{Item 1: The relationship of the reserve guarantor with the drawee}

Escrow is in the favor of the drawee. For the benefit of the drawee, the guarantor can not return to the drawer unless the latter has provided for the payment of the drawee ${ }^{(44)}$. Also, the reserve guarantor may not return the value of the bond to the holder against the endorsers or to their reserve guarantors because the drawee is an original and principal debtor. In another sense. the reserve guarantor shall have recourse only to the drawee and the drawer who does not pay for the fulfillment ,and his collateral for the endorsers is of the general guarantee $^{(45)}$. If a person signs a commercial paper as a guarantor for the drawee, he can not stand in the face of the holder of the commercial paper by the right of recourse to him for negligence and the wisdom of its guaranteed.

The acceptance of the guarantor for the drawee. The French Court of Cassation ${ }^{(46)}$ concludes that the reserve guarantor could guarantee the acceptance of the drawee on it. It is known that the reserve guarantor can guarantee either of the signatories and the drawee who does not sign on the commercial paper. The reason is that the holder of the commercial paper which is not accepted by the drawee who is offered the guarantee, in this case, if he waits for the time of fulfillment and collides with the refusal of the drawee, he can not return to the reserve guarantor to fulfill its amount.That is because the guarantor can not guarantee the fulfillment by the drawee who does not accept and who is not considered a debtor in the commercial paper. This is the legal point that I wanted to mention in the relationship between the guarantor and the drawee in the area of acceptance of the commercial paper, and the previous reference to the due date is permissible on all signatories in the cases described in Article 181/2. The researcher ${ }^{(47)}$ pointed out to an important legal issue that if the drawee is able to persuade the holder of the commercial paper to postpone the claim for its value, the reserve guarantor benefits from the extension of this period and if the holder releases one of the original debtors, guarantor's discharge is based on the acquittal of the guaranteed.

\section{The second item: the relationship of the guarantor with the endorser.}

The endorser in the first place has no guarantor because it is considered to be one of the guarantors in the commercial paper and the provisions of article 185 is applied to him, unless a person discloses his will to guarantee him so explicitly. If the collateral falls on one of the endorsers and the reserve guarantor fulfills the value of the bond on his behalf, the reserve guarantor shall have the right to return to the previous endorsers, the drawer and the drawee with the amount of the payment with the benefits and expenses spent. ${ }^{(49)}$ If we assume that the debit card carries more than one signature and that the guarantor has guaranteed the endorser 2 and fulfill the value of the bond on behalf of the latter, the reserve guarantor is not entitled to return to endorser 3 and the subsequent signatories, but only the right to return to the guaranteed endorser and to the previous signatories : the first endorser, the drawer, the drawee and their reserve guarantors. ${ }^{(50)}$ 
If the holder returns to one of the endorsers of the commercial paper, all his subsequent endorsers and their reserve guarantors are discharged of debit. If the right of the holder to return to the endorsers and their reserve guarantors is lost due to the nullification of the protest against non-fulfillment, this entails the loss of the right of the holder to sign the provisional seizure of their movables. The signing of this attachment is conditional on the validity of the procedures of the protest against non-fulfillment. As for the right of the holder to sue the original debtor of the commercial paper and his guarantor, there is no evidence of invalidation of the protest against him $^{(51)}$. If the holder has fulfilled the duties imposed on him upon his return to the guaranteed endorser, and neglects to perform one of these duties before the guarantor of this endorser, he refrains from the guaranteed endorser of adhering to the negligence of the holder to perform the duties imposed on him before the guarantor. The right to defense in such a case shall be limited only to the collateral guarantor, since the obligation of the secured endorser is not dependent on the obligation of the guarantor and does not occur in contrast to the previous situation. In accordance with Article 53 of the Geneva Act, the guarantors of the endorsers are entitled to defense for the loss of the delinquent holder's right in the bill of withdrawal. in the opposite case. According to article 53 of the Geneva Act, the guarantors of the endorsers are entitled to pay for the loss of the holder's right in the bill of the drawn bond .

If the guaranteed endorser becomes bankrupt, the holder has no right to return to the guarantor who is in charge of him and therefore progress in the bankruptcy of the guaranteed endorser, otherwise his right of recourse to the reserve guarantor will be harmed by the negligence of the holder in accordance with article 978 of the Jordanian Civil Code.$^{(52)}$ But the question is whether the holder of the bond is entitled to return before the due date because of the bankruptcy of the original debtor with the value of the commercial paper? If one of the guarantors in the commercial paper becomes bankrupt - such as the endorser or the guarantor or the drawer after the acceptance - the holder is not allowed to return to the rest of the obligors before the due date, because any of them is an original debtor of the bond value and the bankruptcy is due to the fall of deadlines..

\section{CONCLUSION}

The optional statement of the collateral in the commercial paper is to create a new moral obligation. In order to give full protection to the holders of the commercial paper, the law considers that every person who has entered into the obligation cycle is considered to be personally committed in accordance with the strict exchange rules as collateral added to the guarantees given to the holder of the commercial paper, especially if the obligor is outside the parties to the commercial paper.

The guarantee in all its dimensions, especially in the legal relationship between its parties, has emerged due to practical reasons in response to certain needs in the midst of a banking system that enables it to use the latest and most advanced technologies to ensure the fulfillment of the holder, and that the effect of the collateral in the legal relationship between the guarantor and the holder and the relationship of the guarantor with the guaranteed and the rest of the obligors in the commercial paper. The researcher clarified that there are cases where the guarantee may fall between one of the signatories, and there are cases where it is not permissible, like the drawee may not assign his guarantee to one of the endorsers since the drawer is the original debtor. It is not also permissible for the drawee to be guarantor because he is considered the original debtor. However, it is permissible for the drawer to be the guarantor for the drawee. The collateral can be the signed by the endorser to another endorser because he is considered a guarantor for him, and the purpose is that the dealers in commercial papers know the cases where the collateral may happen .

And to clarify the legal relationship between the parties of the reserve guarantor and to determine their impact among them, this research concludes with a view to the legislative shortcomings that have affected the provisions of this relationship. Here are the following observations and recommendations:

1. Rephrase Article 181, which states that (the holder of the bond when he does not fulfill the date of maturity to return to his endorser and his drawer and other committed). In the case of a collateral, the holder does not have the freedom of choice to return to any of those committed in the commercial paper, he has to return to the guaranteed person, and that the holder does not return to the guarantor in the event that the secured debtor is unable to fulfill the value of the commercial paper or when the drawer or the drawee become bankrupt, he shall be given the option of returning to any of the obligors.

2. The sixth paragraph of article 162, which allows the granting the collateral on a separate sheet of paper and limiting it to the first paragraph of the same article, shall be canceled until the obligation of the guarantor is subject to the rules of exchange, since these rules are subject only to each signatory on the commercial paper or paper related thereto. Thus, the guarantee on the independent paper is not subject to such rules. 
3 . If the collateral may be given on a separate paper, which is often done before establishing the commercial paper, and to facilitate the circulation of it requires the acceptance of drawee, this requires amendment of Article 153 of the Trade Law by adding the guarantee contained in a separate paper in the cases where the holder is committed to provide the bond for the acceptance of the drawee.

4. It is noticed that the article 163/2, which considers the obligation of the reserve guarantor to be true even if the obligation that is guaranteed is invalid for any reason unless there is a defect in the form. If the signature of the guaranteed person is forged, the guarantor is not entitled to hold such defense against the holder pursuant to the above article. So, we recommend that the Jordanian legislator take into account the provisions of the Unified Geneva Law when it terminates the guarantor from fulfilling the payment by falsifying the signature of the secured person when the guarantor, when signing the bond, is considered to have attested to this guarantee , and is therefore aware of what the guaranteed signed. This requires the rewording of the second paragraph of Article 163 by excluding the forgery of the signature of the guaranteed person from the defenses held by the guarantor in the face of the holder of the commercial paper as the guaranteed's request of a collateral from the guarantor is a conclusive presumption and a confirmation by the guarantor of the validity of the obligation of the guaranteed.

\section{REFERENCES:}

(1) Akram Yamlaki.(2001) Commercial Papers In Accordance With The Unified Geneva Conventions Dar alThaqafa for publication and distribution. Amman

(2) Ibrahim Ismail Ibrahim.(1999) The Reserve Security In The Commercial Paper A Legal Study .Dar Al Thaqafa for Publishing and Distribution. Oman.

(3) Bakour al-Mukhtar.(1984) The Reserve Guarantee in the Bill of Lading According to Moroccan Legislation Master Thesis, Faculty of Law Rabat

(4) Jafar Mohammed Muqbel.(2006) Contracts And Commercial Papers. University of Aden 2006.

(5) Hussein Mohammed Saeed. obligations and rights of the holder of a commercial paper. World of Books. Cairo

(6) Helou Abu Helou(2006). Reserve Guarantee in Commercial Papers Comparative Study. Research published in the Yarmouk Journal of Research .Volume 22 Issue 4

(7) Samyha al-Qalioubi.(1992) Commercial Papers. Arab Renaissance House. Cairo Second Edition

(8) Shokri Ahmed Al-Sibai.(1981) Mediator In Moroccan Commercial Law and Compare Part II, Knowledge Library. Rabat

(9) Salahuddin Al-Nahi. (1965) In The Commercial Papers. Baghdad Publishing Company

(10) Salahuddin Al-Nahi.(1962) Mediator in explaining the Iraqi commercial law. Baghdad (11) Aziz Al-Okeili (2011) Mediator In Explaining Commercial Legislation -Dar Al-Thaqafa for Publishing and Distribution Amman edition

(12) Ali Salman Al Obeidi.(1970) Commercial Papers in the Moroccan Legislation First Edition Al - Toumi Library Rabat

(13) Ali Salman Al-Obaidi. (1973) Commercial Papers in Iraqi Law First Edition Dar Al Salaam Press Baghdad

(14) Abdul Qader Al-Atair(1998). The Mediator in Explaining Commercial Law -Comparative Study Dar Al Thaqafa for Publishing and Distribution Amman

(15) Abdullah Mohammed Al-Omran(1995) .Commercial Papers In The Saudi System Dar Al-Yazuri for publication and distribution. Amman

(16) Ali Al-Arif.(1984) Explanation of the Commercial Law Part II, First Edition Attaya Press. Egypt. 
(17) Ali Baroudi(1989). Commercial Law Commercial Securities and Bankruptcy. University House Beirut.

(18) Fayad Mlefi Al Qudah(2009) . Explaining Commercial Law Dar Wael Publishing Amman. First Edition

(19) Fawzi Mohammed Sami(2008) .Explanation of Commercial Law Part II Dar al-Thaqafa for publication and distribution Amman edition

(20) Mahmoud Samir Al - Sharqawi(1981) .Commercial Law, Part II, Dar Al - Nahda Al - Arabiya Cairo

(21) Mohsen Shafiq(1972), Kuwaiti Commercial Law.

(22) Mahmoud al-Kilani.(2007) Encyclopedia of Business and Banking, Volume III, Comparative Study, Dar Al-Thaqafa Publishing and Distribution.

(23) Mahmoud Mohamed Salem(1977) . Falling And Obsolescence In Commercial Papers, House of authorship Press

(24) Mohammed Ali Rateb.(1984) Bond notes. First Edition, Cairo.

(25) Yacoub Yousef Sarkhwa.(1999). Commercial Papers in Kuwait Commercial Law Comparative Study First Edition

\section{FOREIGN REFERENCES}

Friedel Georges- (1978) de 1, inopposabilite des exceptions mattered. Effects de - commerce Michel- la letter de change dans la jurisprudence, librairietechnigues, 2eme edition Cabrillac

(1) Kuwait Trade Law No. 68 of 1980 Articles 449-450, Qatar Trade Law No. 27 of 2006 Articles 499-502, Moroccan Trade Code Part 5 Article 180.

(2) Dr. Aqeeli Aziz, custom reserve is a reserve (secured by a fixed debt in bond). Al - Waseet in explaining commercial legislation Dar Al - Thaqafa for Publishing and Distribution. Oman. Print this page 344 See d. Kilani Mahmoud. Encyclopedia of Commercial and Banking Volume II. Commercial Papers. Dar Al Thaqafa for Publishing and Distribution. Oman. Edition 2007 page 233, also d. Al-Atair Abdul Qader. Broker in explaining commercial law, commercial papers. Dar Al Thaqafa for Publishing and Distribution. Oman. Print page.

(3) Article $(162 / 5+6)$ (The reserve security may be given to an independent instrument indicating the place where it was made). Paragraph 6 provides that (and the reserve guarantor is an independent instrument that is committed to what he guarantees). See Al-Shalali Ja'far Mohammed : Contracts and Commercial Papers issued by the University of Aden First Edition 2006 Page 315. Article 162/2 guarantees the payment of the value of the commercial paper in order to return this guarantee on the same bond or in a separate paper. This is what was endorsed by the Egyptian Court of Cassation Appeal No. 119 years 34 session. Dr. . Hosny Ahmed Mahmoud the district of the cassation of trade _ the principles decided by the Court of Cassation in 68 years 1931-1993 The Facility of Knowledge Alexandria edition 2000 Page 192.

(4) Which states that (1) The guarantor is bound by the obligation of the secured person. 2. The guarantor's obligation is true if the obligation which is secured is void for any reason unless it is due to a defect in the form

(5) Dr.. Said Hussein Mohammed - Obligations and the holder's right of the commercial paper . Dar Alam Al -Kutub. Cairo without the date of publication Page 69.

(6) Dr. Al - Obeidi Ali Salman- the Commercial papers in Iraqi law Dar Al- Salaam Baghdad edition 1973 Page 412.

(7) Dr. Yamalki Akram, Commercial Papers in Accordance with the Consolidated Geneva Conventions and Banking Operations . Dar Al-Thaqafa for Publishing and Distribution-Amman First Edition 2001- page 193, Dr. 
Al-Omran Mohammed-The Commercial Papers in the Saudi System-Dar Al-Yazuri Scientific for Publishing and Distribution-Edition 1995-page 182.

(8) Dr. Al-Obeidi Ali Salman M. O Commercial papers in Iraqi law, page 412.

(9) Dr. Yamalki Akram. s. Page 193.

(10) Dr. Baroudi Ali, Commercial Law Commercial Papers. University House. Beirut edition 1989. Page 148

(11) Dr. Ibrahim Ismail Ibrahim - Reserve in the Commercial Securities- a Legal Study, Dar Al-Thaqafa for Publishing and Distribution Amman 1999 Page 119.

(12) Ruling of the Egyptian Commercial Court 22 / 1/1950 Egyptian law year 30 No. 385 Page 801.

(13) Dr. Al - Nahi Salah al - Din, the mediator in the explanation of the Iraqi law- Commercial papers- fourth edition Baghdad 1962 Page 402.

(14) D. Yamalki Akram -Commercial Papers. 2001 edition. Abdullah Mohammed Al Omran- Trading papers in the Saudi system m. s.

(15) Dr. Oqaili Aziz. The Mediator in explaining the commercial legislation-m.s. page 346 Dr.. Yacoub Youssef Sarkhwa Commercial Papers in Kuwaiti Law -Comparative Study First Edition 1996, p. 200

(16) Discrimination of Rights No. 4547/2004, which stated that "the rule of cleansing cleanses the defenses which has been denied to those who were brought to them by protesting against the holder by defenses based on their personal relationship to the person who took the bond even if the cause of debit is void ...". Through Dr. Fayyad Al-Qudah. Edition 2009 page 122.

(17) Article 1005 of the Civil Code stipulates that "the assignee may have to hold against the assignor all the defenses related to the debt that he had in the face of the assignor and he may hold all defenses to the assignor before the assignee"

(18) With regard the good -intentional holder of the commercial paper, see the judgments of the Egyptian Court of Cassation, Appeal No. 1507, year 55, session 1/11/1993, appeal No. 620, year 59, 13/9/1993, appeal No. 1438, year 56, , Hosny Ahmed Mahmoud. Commercial Cassation Court. 30. The holder was considered to be ill-intentioned merely because he knew that there was a payment that the debtor could direct to the endorse, even if the collusion between the latter and the debtor was not proven to deprive the debtor of payment. Appeal No. 978, 49 BC, 9/1/1984 Hosni Ahmed, See page 179. d. Ibrahim Ibrahim Ismail, MS Page 115.

(19)Article 124 relating to statements of withdrawal document, Article 222 relating to bond data, Article 228.relating to check data.

(20)States that (if the bond carries signatures of persons who are not qualified for it, false signatures, signatures of fictitious persons or signatures that do not otherwise bind the persons who signed or signed on their behalf, that does not preclude the validity of the obligation of the other signatories).

(21) Dr. Fayyad Al Qudah is canceled. Jordanian Commercial Law- Commercial Papers , Dar Wael for Publishing, First edition, Amman Page 130.

(22) Dr. Obeidi Ali Salman. Commercial Papers in Moroccan Legislation, Rabat, 1970, p289

(23) Friedel Georges- (1978) de 1, inopposabilite des exceptions mattered. Effects de - commerce Michel- la letter de change dans la jurisprudence, librairietechnigues, 2eme edition Cabrillac 19 p.133,138,139.

(24) cabrillac(m.) -la letter de change dans la jurisprudence, libraries techniques,(Paris)

(25) Dr. Al Nahi Salahuddin, The Mediator in commercial papers. Al Ahlia Company for Publishing and Distribution, Baghdad edition 1965, page 411

(26) On the principle of good faith see Dr. Al-Kilani Mahmoud MS Page 149 and beyond

(27) Dr. Al-Arif Ali, Explanation of the Egyptian Commercial Law, MS, pp. 114 et seq. Also see Dr. Sbai Shukri Ahmed .The Mediator in Moroccan Commercial Law Part II Library of Knowledge Rabat 1981 Edition Page 99. 
(28) Dr Sbai Shukri Ahmed.MS.page 106

(29) The decision of the Jordanian Court of Cassation in its capacity as No. 246/87 is published in the Journal of the Jordanian Bar Association for the year 1990, and resolution No. 891/93, published in the Journal of the Bar Association, 1993, page 292.

(30) Dr. Obeidi Ali Salman. Commercial Papers in Moroccan Legislation, Rabat, 1970, p.413

(31) Dr. Aqili Aziz . The Mediator in explaining the commercial legislation Dar Al-Thaqafa for Publishing and Distribution Oman Edition 2011 Page 345, Mohsen Shafiq Kuwaiti Commercial Law Kuwait University 1972 Page 497.

(32)Dr. Al Qudah Fayyad. M. O Page 200.

(33) Dr. Al-Omran Abdullah Mohammed, Commercial Papers in the Saudi System, Dar Al-Yazuri for Publishing and Distribution, Amman, 1995 edition, page 182, d. Sbai Shukri Ahmed, the Mediator in Moroccan and Comparative Business Law, Library of Knowledge, Rabat, page 97.

(34) Dr. Ibrahim Ismail, MS Page 135.

(35)Dr. Rateb Muhammad Ali, A trial Bonds, First Edition, Cairo 1948, p. 228 et

(36) Dr. Al - Sharkawi Mahmoud Samir- Commercial Law, Part II Dar al - Nahda Al -Arabia Cairo edition 1981 Page 385.

(37)Dr.Saeed Hussein Mohammed. Obligations and Rights of the Holder of the Commercial P.73

(38) Dr. Obeidi Ali Saman .MS. Commercial Papers in Moroccan Legislation, Rabat, 1970, p. 287 See also DSalem Mahmoud Mohamed. Falling and limitations in commercial papers. M.S. Page 227.

(39) Dr. AL -Qudah Fayyad, Explanation of Commercial Law. - Commercial Papers Page $203+204$.

(40) Dr. Al Oqaili Aziz. Mediator in explaining the commercial legislation. Dar Al-Thaqafa for Publishing and Distribution-Amman 2011-Page 143.

(41) Dr. Al Nahi Salah Al - Din. Al-Mabsout in Commercial Papers - Ahlia Company For publishing Baghdad 1965 - Page 421 and beyond.

(42) Dr.. Ibrahim Ismail Ibrahim - page 143.

(43) Dr.. Salem Mahmoud Mohamed. MS, p. 227 and beyond.

(44) Dr.. Al-Otair Abdul Qader The Mediator in explaining commercial law MS, page 192 and beyond, Dr. Nahi saladin m.s page 412

(45) Dr.. Sibai Shukry M. Page.103

(46) Through the author Dr. Ibrahim Ismail MS page 152.

(47) Dr.. Salah Al - Din Al - Naihi .The Mediator in explaining the Iraqi commercial law provisions of commercial papers Baghdad 1962 page 402, 403.

(48) discharge is one of the reasons leading to the expiration of the obligation and this is stipulated in Article 444 of the Jordanian Civil Code.

(49) Dr. Al - Obaidi Ali Salman Commercial paers.

(50) D. Al-Atair Abdul Qader. Thev Mediator in explaining the Commercial Law, p.238

(51) Ruling issued by the Court of First Instance in Alexandria 20/3/1940 Law Journal Sind 20, page 983, see regarding the return of the holder to the endorsers and their guarantors Appeal No. 30 years $38 \mathrm{~S}$ session 31/3/1973, appeal No. 398 years 38 S session 31/2/1974 Appeal No. 1507 In 55 years session of 1/11/1993, as for the condition of hunger without expenses and exemption of the pregnant woman from the protest work, see appeal No. 259 years 38 BC session 13/11/1973 d - Ahmed Mahmoud Hosny - m. Pp. 194, 195,198. 
(51) Which states that (if the debtor becomes a bankrupt, the creditor must present bankruptcy in debt or else his right to recourse to the guarantor will be as much as the consequent relaxation of the damage). 